\title{
The Impact of Marketing Communications on Buying Silver Online: Study on Young Generation's Perception in Malaysia
}

\author{
Chai-Lee Goi, Hui-Yiing Fu, Wen-Yi Ting, Wei-Yii Goh, and Siaw-Kang Chin
}

\begin{abstract}
The main objective of this research is to study the impact of marketing communications on buying silver online, especially perception of young generation in Malaysia. This study found that all marketing communications tools, advertising, online marketing, personal selling, public relations and sales promotion are important and significant impact on buying silver online.
\end{abstract}

Index Terms-Advertising, online marketing, personal selling, public relations, sales promotion.

\section{INTRODUCTION}

There are several categories in which online sales dominate each product marketplace. The following infographic shows the summary of the outcome of the data [1], [2] (see Fig. 1):

- Drugs and health aids are two most important retail categories, and it is under-represented in E-Commerce. However, only $8.8 \%$ of the total sales are made online.

- People are buying more clothes online than offline (\$13.6B vs \$7.0B).

- There are several sectors where E-Commerce dominates offline sales. This includes books, electronics, food, beer and wine, furniture, and music and videos.

According to Jiang, Yang and Jun [3], "as consumers allocate less time to shopping and more to other endeavors, their desire for convenience has mounted and their attention has been frequently diverted to virtual shopping as an alternative medium". Even, their research showed that there are five dimensions of online shopping convenience, which are access, search, evaluation, transaction, and possession/post-purchase convenience.

\section{OBJECTIVE}

"Gold and silver have wide-ranging utility from their use in art and jewelry to their use in the production of electronic

Manuscript received May 11, 2013; revised July 13, 2013

Chai-Lee Goi, Hui-Yiing Fu, Wen-Yi Ting, Wei-Yii Goh, and Siaw-Kang Chin are with School of Business, Curtin University, CDT 250, 98009 Miri, Sarawak, Malaysia (e-mail: goi.chai.lee@curtin.edu.my, e7e0a7273@student.curtin.edu.my, 7e0a7388@student.curtin.edu.my, 7e0a7520@student.curtin.edu.my,7e0a7593@student.curtin.edu.my). equipment. The holding of gold and silver has always been considered a great treasure. Within the last decade a new use has developed for these metals: Individual investors and portfolio managers have recently begun to view them as possible investment assets. There is a trend nowadays in Malaysia where people are buying gold and silver online. However, not much research has been done related to consumer online buying behavior especially silver" [4].

Thus, the main objective of this research is to study the impact of marketing communications on buying silver online, especially perception of young generation in Malaysia.

The main focus group will be on young generation because a study from Nielsen [5] founded that the highest usage was recorded among people aged 20-24 and almost six in ten $(57 \%)$ regularly use the Internet.

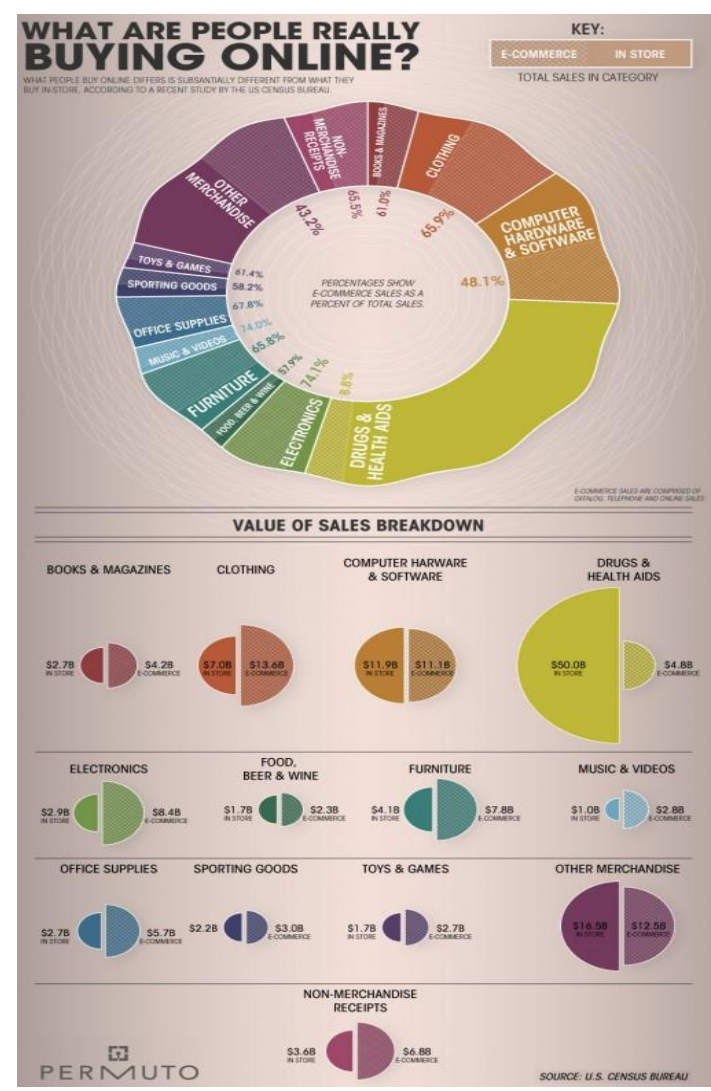

Fig. 1. What are people really buying online? (Adapted from [1], [2])

\section{Methodology}

Primary data were collected using a self-administered 
questionnaire to serve the purpose of the research objective. First part of the questionnaire is based on demographics and second part of the questionnaire will be based on 5-points of Likert Scale. Five factors of the marketing communications are included in this questionnaire: advertising, online marketing, and personal selling, public relations and sales promotion.

Questionnaires were randomly distributed to the respondents. Only respondents 39 of age or below will be selected. Overall, only 188 valid questionnaires were used and analysed.

SPSS is used for the purpose of analysing descriptive analysis, correlations of coefficient and ANOVA.

\section{LITERATURE REVIEW}

\section{A. Overview}

Traditionally, there are five main marketing communications, which are advertising, sales promotion, personal selling, public relations and direct marketing. There were variations reflecting particular brand circumstances, but essentially in the B2C market advertising was used to build brand values, sales promotions were used to encourage customer action, and public relations sought to generate goodwill and interest of the company. Personal selling was regarded as the primary tool in B2B markets. In the 1990s, direct marketing became a more prominent tool in the mix because technology had enabled a form of communication by appealing personally and directly to the target customer. This change introduced new media formats, and the subsequent development of the Internet and related digital technologies has accelerated change within the marketing communications industry [6].

\section{B. Advertising}

Advertising is a promotional tool that informs customers regarding product information, such as product availability, price, function, manufacture, and more [7]. According to Jedidi, Mela and Gupta [8], advertising brings both short and long-term effect in terms of increasing consumer's brand choice utility and reducing their price sensitivity.

\section{Sales Promotion}

According to Steenkamp et al. [9], sales promotion helps to increase customer's price sensitivity, induce brand switchers and create product trials, which enhance brand awareness. Sales promotion usually lowers the price of products for a larger purchasing quantity. As a result, it enhances customer's perceived value of product price, leading towards the incentive to make the purchase decisions [10] [11].

\section{Personal Selling}

According to O'Hara [12], the main purpose of personal selling is to satisfy the long-term wants and needs of consumers. Personal selling is necessary in a sense that customers only buy from dealers who possess expertise, product knowledge and good reputation [13]. Weitz and Bradford [14] stated that organisations often implement personal selling in order to better manage buyer's objections and the conflicts arise in the relationships between buyers and business firms.

\section{E. Public Relations}

Public relations involve sponsorships and news publication to attract new customers and perform corporate social responsibility. Public relations are referring to build good relations with the public through publicity to improve corporate image and to uphold stakeholders' interests [15]. Also, public relations are able to raise public awareness at a much lower cost [16]. Besides, Naveed [17] stated that well-executed public relation can bring about customer loyalty.

\section{F. Online Marketing}

There are several types of online marketing channels utilised by marketers to carry out promotion, which includes banner, e-mails and promotions [18]. According to Tudin and Ling [16], customers are interested to buy products if the advertisement is meaningful and persuasive. However, Tudin and Ling [16] also stated that consumers may feel annoyed when they receive junk mails and banner screening.

\section{RESUlTS AND DISCUSSION}

\section{A. Demographics}

A total of 188 samples were obtained. In total, 161 respondents are female and 67 are male respondents. Most of the respondents are aged between 20 and 29, accounting for 64.89 percent. The rests are respondents aged 19 or less $(7.45$ percent) and respondents aged between 30 and 39 (27.66 percent).

The largest sample obtained is Chinese. This includes a total of 109 respondents or 57.98 percent. This is followed by the Malay, Indian and others.

In terms of education, 79 respondents have their bachelor degree. This is followed by diploma/ certificate holders (42 respondents) and secondary school certificate holders (40 respondents). The rests are those who are graduated from primary school (3 respondents) and postgraduate (24 respondents).

In terms of income, the largest percentage of their income is less than RM800. Of the 188 samples, a total of 69 respondents are in this group. The other important groups are those earning between RM2000 to RM2999 (29 respondents), those earning RM5000 and above (26 respondents), and those earning between RM1000 to RM1999 (25 respondents). The rests are those earning between RM3000 to RM3999, RM4000 to RM4999, and RM800 to RM999 (see Table I).

\section{B. Reliability}

In order to test the reliability, Cronbach's alpha score is evaluated. An alpha of 0.7 and above is regarded as acceptable for assuming homogeneity of items [19]. The analysis from this study shows that an overall reliability (Cronbach's $\alpha$ ) is 0.729 . This value can be considered as an acceptable value because it has been exceeding 0.7 , which is an acceptable value (see Table II).

\section{Descriptive Analysis}

An overall of mean score for marketing communications is 
3.2379. This value can be considered as a well-accepted value. Majority of respondents realised that marketing communications has a significant impact on buying silver online (see Table III). Based on analysis of each variable of marketing communications, all variables are at least 3.0851 and above. This study clearly shows that the highest mean score is sales promotions, which is 3.5000 , and the lowest mean score is public relations. The mean score is 3.0851 (see Table IV).

Pearson correlations are computed to determine if there are significant relationships between advertising, sales promotion, personal selling, public relations and online marketing.

Table IV is also demonstrates the correlation coefficients between the study variables. The correlation coefficient ranged from 0.178 to 0.538 . All these correlations can be grouped under three categories: no correlation (0.0) and weak positive correlation $(0.25)$, weak positive correlation (0.25) and moderate correlation (0.50), and moderate positive correlation (0.50) and strong positive correlation (0.75). Another important finding is all correlations are significant either at the 0.01 or 0.05 level.

\begin{tabular}{|c|c|c|c|c|}
\hline \multirow[b]{2}{*}{ Gender } & \multicolumn{3}{|c|}{ Age } & \multirow[b]{2}{*}{ Total } \\
\hline & 19 or less & $20-29$ & $30-39$ & \\
\hline Male & 7 & 41 & 19 & 67 \\
\hline Female & 7 & 81 & 33 & 121 \\
\hline Total & 14 & 122 & 52 & 188 \\
\hline \multicolumn{5}{|l|}{ Race } \\
\hline Chinese & 11 & 67 & 31 & 109 \\
\hline Malay & 1 & 33 & 7 & 41 \\
\hline Indian & 2 & 16 & 5 & 23 \\
\hline Others & 0 & 6 & 9 & 15 \\
\hline Total & 14 & 122 & 52 & 188 \\
\hline \multicolumn{5}{|l|}{ Education } \\
\hline Primary school & 1 & 2 & 0 & 3 \\
\hline Secondary school & 9 & 23 & 8 & 40 \\
\hline Diploma/Certificate & 2 & 28 & 12 & 42 \\
\hline Bachelor of Degree & 1 & 62 & 16 & 79 \\
\hline Postgraduate & 1 & 7 & 16 & 24 \\
\hline Total & 14 & 122 & 52 & 188 \\
\hline \multicolumn{5}{|l|}{ Income (Per Month) } \\
\hline Less than RM 800 & 8 & 58 & 3 & 69 \\
\hline RM 800 - RM 999 & 4 & 6 & 1 & 11 \\
\hline RM 1000 - RM 1999 & 0 & 22 & 3 & 25 \\
\hline RM 2000 - RM 2999 & 2 & 14 & 13 & 29 \\
\hline RM 3000 - RM 3999 & 0 & 9 & 6 & 15 \\
\hline RM 4000 - RM 4999 & 0 & 4 & 9 & 13 \\
\hline RM 5000 and above & 0 & 9 & 17 & 26 \\
\hline Total & 14 & 122 & 52 & 188 \\
\hline
\end{tabular}

TABLE II: RELIABILITY

\begin{tabular}{llrr}
\hline \hline N of Items & & Cronbach's Alpha \\
\hline 5 & & & .729 \\
\hline \hline \multicolumn{4}{l}{ TABLE III: MARKETING COMMUNICATIONS } \\
\hline \hline & $\mathrm{N}$ & Mean & Std. Deviation \\
\hline Marketing Communications & 188 & 3.2479 & .75519 \\
\hline \hline
\end{tabular}

\section{Comparison between Age Groups}

Based on a comparison of three groups, 19 or less, 20-29 and 30-39, a result shows that the mean score for all variables can be considered as positive and acceptable. Overall, the perception of the age group between 20-29 is higher than the other two age groups. This can be referred to all mean score for variables except (see Table V).

TABLE IV: MARKETING COMMUNICATIONS TOOLS

\begin{tabular}{lllllll}
\hline \hline & Mean & 1 & 2 & 3 & 4 & 5 \\
\hline Advertising & 3.2234 & & & & \\
Sales Promotion & 3.5000 & $.436^{* *}$ & & & & \\
Personal Selling & 3.1223 & $.178^{* *}$ & $.231^{* *}$ & & \\
Public Relations & 3.0851 & $.346^{* *}$ & $.425^{* *}$ & $.431^{* *}$ & \\
Online Marketing & 3.3085 & $.413^{* *}$ & $.314^{* *}$ & $.219^{* *}$ & $.538^{* *}$ \\
\hline \hline
\end{tabular}

**. Correlation is significant at the 0.01 level (2-tailed).

*. Correlation is significant at the 0.05 level (2-tailed).

TABLE V: DESCRIPTIVE ANALYSIS

\begin{tabular}{|c|c|c|c|c|}
\hline & Age & $\mathrm{N}$ & Mean & $\begin{array}{r}\text { Std. } \\
\text { Deviation }\end{array}$ \\
\hline \multirow{4}{*}{ Advertising } & $\begin{array}{l}19 \text { or } \\
\text { less }\end{array}$ & 14 & 2.929 & 1.14114 \\
\hline & $20-29$ & 122 & 3.230 & 1.11923 \\
\hline & $30-39$ & 52 & 3.289 & 1.16040 \\
\hline & Total & 188 & 3.223 & 1.12961 \\
\hline \multirow[t]{4}{*}{ Sales Promotion } & $\begin{array}{l}19 \text { or } \\
\text { less }\end{array}$ & 14 & 3.357 & 1.00821 \\
\hline & $20-29$ & 122 & 3.525 & 1.04615 \\
\hline & $30-39$ & 52 & 3.481 & 1.05701 \\
\hline & Total & 188 & 3.500 & 1.04190 \\
\hline \multirow[t]{4}{*}{ Personal Selling } & $\begin{array}{l}19 \text { or } \\
\text { less }\end{array}$ & 14 & 3.071 & 1.07161 \\
\hline & $20-29$ & 122 & 3.172 & 1.17616 \\
\hline & $30-39$ & 52 & 3.019 & 1.09348 \\
\hline & Total & 188 & 3.122 & 1.14272 \\
\hline \multirow[t]{4}{*}{ Public Relations } & $\begin{array}{l}19 \text { or } \\
\text { less }\end{array}$ & 14 & 2.786 & 0.97496 \\
\hline & $20-29$ & 122 & 3.123 & 1.11769 \\
\hline & $30-39$ & 52 & 3.077 & 1.04499 \\
\hline & Total & 188 & 3.085 & 1.08622 \\
\hline \multirow[t]{4}{*}{ Online Marketing } & $\begin{array}{l}19 \text { or } \\
\text { less }\end{array}$ & 14 & 3.214 & 0.80178 \\
\hline & $20-29$ & 122 & 3.336 & 1.06492 \\
\hline & $30-39$ & 52 & 3.269 & 1.06854 \\
\hline & Total & 188 & 3.309 & 1.04474 \\
\hline
\end{tabular}

Based on a comparison of three age groups, the study shows that there are no significant difference perception in terms of advertising, sales promotion, personal selling public relations and online marketing. This can be referred Table VI.

TABLE VI: ANOVA

\begin{tabular}{lccl}
\hline \hline & F & Sig. & Decision \\
\hline Advertising & 0.562 & 0.571 & No Difference \\
Sales Promotion & 0.173 & 0.841 & No Difference \\
Personal Selling & 0.339 & 0.713 & No Difference \\
Public Relations & 0.605 & 0.547 & No Difference \\
Online Marketing & 0.135 & 0.874 & No Difference \\
\hline \hline
\end{tabular}

\section{CONCLUSION}

The study on young generation perception shows that marketing communications has a significant impact on buying silver online. This can be referred to the overall mean score is 3.2479. Secondly, the mean score for all marketing 
communications' variables are between 3.0851 and 3.5000 . Finally, all correlations between variables are positive.

\section{REFERENCES}

[1] What are people really buying online? Brainsins. (2012). [Online]. Available:

http://www.brainsins.com/us/blog/what-are-people-really-buying-onli ne-infographic

[2] United States Census Bureau. [Online]. Available: http://www.census.gov

[3] L. Jiang, Z. Yang, and M. Jun, "Measuring consumer perceptions of online shopping convenience," Journal of Service Management, vol 24, no. 2, pp. 191-214, 2013.

[4] M. E. Solt and P. J. Swanson, "On the efficiency of the markets for gold and silver," The Journal of Business, vol. 54, no. 3, pp. 453-478, 1981

[5] Malaysian internet usage takes off in 2010. Nielsen. [Online]. Available:

http://www.nielsen.com/us/en/newswire/2011/malaysian-internet-usa ge-takes-off-in-2010.html

[6] C. Fill and B. Jamieson. (2006). Marketing communications. Edinburgh Business School Heriot-Watt University. Great Britain. [Online].

Available: http://www.ebsglobal.net/en/documents/course-tasters/english/pdf/h1 7mm-bk-taster.pdf

[7] S. Schwarzkopf, "What was advertising? The invention, rise, demise, and disappearance of advertising concepts in nineteenth- and twentieth-Century Europe and America," presented at the BHC Annual Meeting, Milan, Italy, June 11-13, 2009.

[8] K. Jedidi, C. F. Mela, and S. Gupta, "Managing advertising and promotion for long-run profitability," Marketing Science, vol. 18, no. 1, pp. 1-22, 1999.

[9] J. E. M. Steenkamp, V. R. Nijs, D. M. Hanssens, and M. G. Dekimpe, "Competitive reactions to advertising and promotion attacks," Marketing Science, vo. 24, no. 1, 2005.

[10] P. Raghubir and K. Corfman, "When do price promotions affect pretrial brand evaluations?" Journal of Marketing Research, vol. 36, no. 2, pp. 211-222, May 1999.

[11] S. Osman, B. Y. F. Chan, and S. F. Yeoh, "Simulation of sales promotions towards buying behaviour among university Students," International Journal of Marketing Studies, vol. 3, no. 3, pp. 78-88, 2011.

[12] B. S. O'Hara, "Evaluating the effectiveness of trade shows: A personal selling perspective," The Journal of Personal Selling and Sales Management, vol. 13, no. 3, pp. 67-77, 1993.

[13] J. Riley. (September 23, 2012). Promotional mix - Personal selling. Tutor $2 \mathrm{u}$. [Online]. Available: http://tutor2u.net/business/marketing/promotion_personalselling.asp

[14] B. A. Weitz and K. D. Bradford, "Personal selling and sales management: A relationship marketing perspective," Journal of the Academy of Marketing Science, vol. 27, issue 2, pp. 241-254, 1999.

[15] P. Kotler, S. Adam, S. Denize, and G. Armstrong, "Principles of marketing," NSW: Pearson Education Australia, 2009.

[16] R. Tudin and A. L. L. Wong, "Promotion mix: Level of awareness and purchase likelihood," Working Paper Series No. 1201, Faculty of Economics \& Business. Universiti Malaysia Sarawak, 2012.

[17] N. Naveed, "Role of social media on public relation, brand involvement and brand commitment," Interdisciplinary Journal of Contemporary Research in Business, vol. 3, issue 9, pp. 904-913, 2012.

[18] R. K. Diah, B. Prijanto, and S. Noviyana, "Promotion mix in the Internet as an effective tool to influence purchasing decision of Ring Back Tone (RBT)," presented at the 2012 Bangkok International Academic Conference, Bangkok, Thailand, March 12-14, 2012.

[19] R. Burns and R. Burns, "Business research methods and statistics using SPSS,” UK: Sage Publications Ltd, 2008
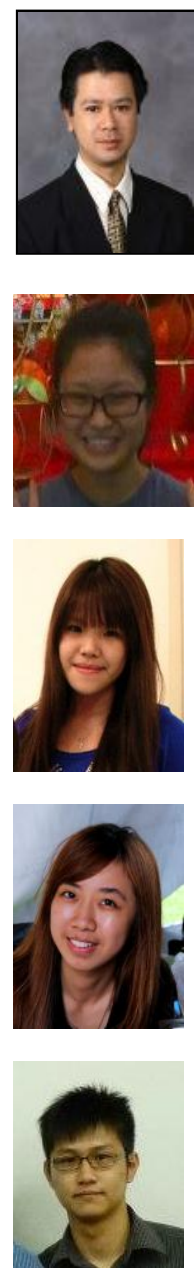

Chai-Lee Goi is a senior lecturer at Department of Marketing and Management, School of Business, Curtin University, Sarawak Campus. He holds a $\mathrm{PhD}$ in Management/ Business from Management and Science, Malaysia. He taught marketing related units, marketing, marketing research and consumer behavior. His research interests are related to marketing especially consumer behavoiur and Internet marketing.

Hui-Yiing Fu is currently a bachelor of Commerce (Finance and Marketing)'s student at School of Business, Curtin University, Sarawak Campus.

Wen-Yi Ting is currently a bachelor of Commerce (Finance and Marketing)'s student at School of Business, Curtin University, Sarawak Campus.

Wei-Yii Goh is currently a bachelor of Commerce (Entrepreneurship and Marketing)'s student at School of Business, Curtin University, Sarawak Campus.

Siaw-Kang Chin is currently a bachelor of Commerce (Finance and Marketing)'s student at School of Business, Curtin University, Sarawak Campus. 